\title{
A survey of forage-related toxicities in goats in Region XII, Philippines
}

\author{
F.R.P. Salvaña ${ }^{1,2,3 *}$, E.G. Sepelagio ${ }^{1}$, C.B. Sanchez ${ }^{4}$, L.B. Cardenas ${ }^{5}$
}

${ }^{1}$ Department of Biological Sciences, College of Arts and Sciences, University of Southern Mindanao, KabacanCotabato; ${ }^{2}$ Graduate School, University of the Philippines Los Baños, College, Laguna; ${ }^{3}$ Philippine Council for Agriculture, Aquatics and Natural Resources Research and Development (DOST-PCAARRD), Brgy. Timugan, Los Baños, Laguna; ${ }^{4}$ Department of Basic Veterinary SciencesCollege of Veterinary Medicine, University of Southern Mindanao, Kabacan, Cotabato; ${ }^{5}$ Plant Biology Division, Institute of Biological Sciences, College of Arts and Sciences, University of the Philippines Los Baños, Laguna, Philippines.

*Corresponding author e-mail: rdsalvana@usm.edu.phhttps://orcid.org/0000-0002-1915-8719

Journal of Livestock Scienc (ISSN online 2277-6214) 12: 170-175

Received on 6/4/21, Accepted on 20/5/21, Published on 8/5/21

doi.10.33259/JLivestSci.2021.170-175

\begin{abstract}
This study aims to determine cases of animal toxicosis attributed to the consumption of a particular plant species. The study was conducted in 12 areas namely Pigcawayan, Aleosan, Carmen, Kabacan, Columbio, Pres. Quirino, Tacurong, Isulan, Tantangan, Tupi, Polomolok and General Santos. A total of 131 respondents were interviewed. Face to face interview was done on selected respondents. A semi-structured questionnaire was used which include cases of toxicosis due to consumption of specific forage. A total of 11 plant-related toxicosis were recorded based on the observation and experience of goat raisers. The most common case is diarrhea due to overconsumption of Gmelinaleaves (29\%). Other toxicity cases recorded were attributed to the consumption of Chromolaenaodorataleaves Phaseoluslunatusleaves (12\%), Vignaradiatafruit (3\%) and overconsumption of Leucaenaleucocephala(3\%), Saccharumspontaneum(3\%) and Manihotesculenta(3\%). Rangeland where these goats are raised is dominated with these plants which increases the possibility of consumption, thus, enhances cases of toxicosis. The result of the study reflects the necessity of establishing proper feeding ratio and management can be done to eliminate the toxic effects if some of these plants will be used as feed for goats.
\end{abstract}

Keywords: toxic plants;goats; forage;toxicosis; Philippines 


\section{Introduction}

In animals, it can be noted that plant related poisoning is due to either accidental ingestion of material consumed along with forages or willful consumption of poisonous plants (Mugera, 1970). Various studies suggest that plant-related toxicosis is common to livestock animals considering their diet composition. Moreover, their capacity to access preferred and desirable plant species is also associated with poisoning events. Limited pasture results in an increasing incidence of animal poisoning (Damiran and Darambazar, 2003). Non-conventional forage as a supplement to the poor quality and inadequate grasses during the dry season can be also attributed to plantrelated poisoning which is common in the tropics (Olafadehan, 2011).

Unlike the public's perception of a goat, an animal that can eat everything from a tin can to plastic wrapping, there are many things that can be detrimental to goats. Some poisonous plants are accidentally ingested while browsing. However, the majority of goat poisoning comes as a result of starvation. Goats may eat unpalatable weeds and wild shrubs that may be poisonous. Most literature suggests that goats are often not affected by poisonous compounds or anti-nutritional factors if a sufficient number of high quality forages are available. Since goats prefer to consume a very varied diet, the detrimental effects of poisonous compounds found is a certain forage can be diluted (Luginbuhl, 2006). Poisoning events also depend on grazing behavior and animal susceptibility to plant toxins. In most cases, lesser production losses are observed when animals grazed on several species of forages compared to single species consumption. Moreover, variations on the palatability of plants to animals also affect cases of poisoning (Ralphs and Provenza, 1990).

Case reports on plant-related animal toxicosis are limited. These events are seldom evaluated by livestock technicians especially in backyard raising. More often than not, parasitic infections and other infectious diseases are emphasized. Losses due to goat poisoning are also evident. Navarra et al. (2019) recorded more than 60 death cases recorded in the Bangsamoro Autonomous Region in Muslim Mindanao (BARMM)and this mortality, according to raisers, is due to overconsumption of Urenalobata which is the only available forage during that period. Cardiac glycoside, a toxic compound to most animals, is present in this plant which can be the main reason for the recorded mortality (Fagbohun et al., 2012).

This study aims to determine plant-related toxicosis of goats, specifically in Region XII, Philippines. Goat population in the region reaches 226,794 which accounts for $4.90 \%$ of the total population in the country as of 2018 (PSA, 2018). To date, there are no available information on the plant-related toxicosis in the region.

\section{Materials and methods}

Location of the study

The study was conducted in selected areas of Region XII- Phillipines. Respondents were from 12 sampling areas in the region: Pigcawayan, Aleosan, Carmen, Kabacan, Columbio, Pres. Quirino, Tacurong, Isulan, Tantangan, Tupi, Polomolok and General Santos (Fig. 1).

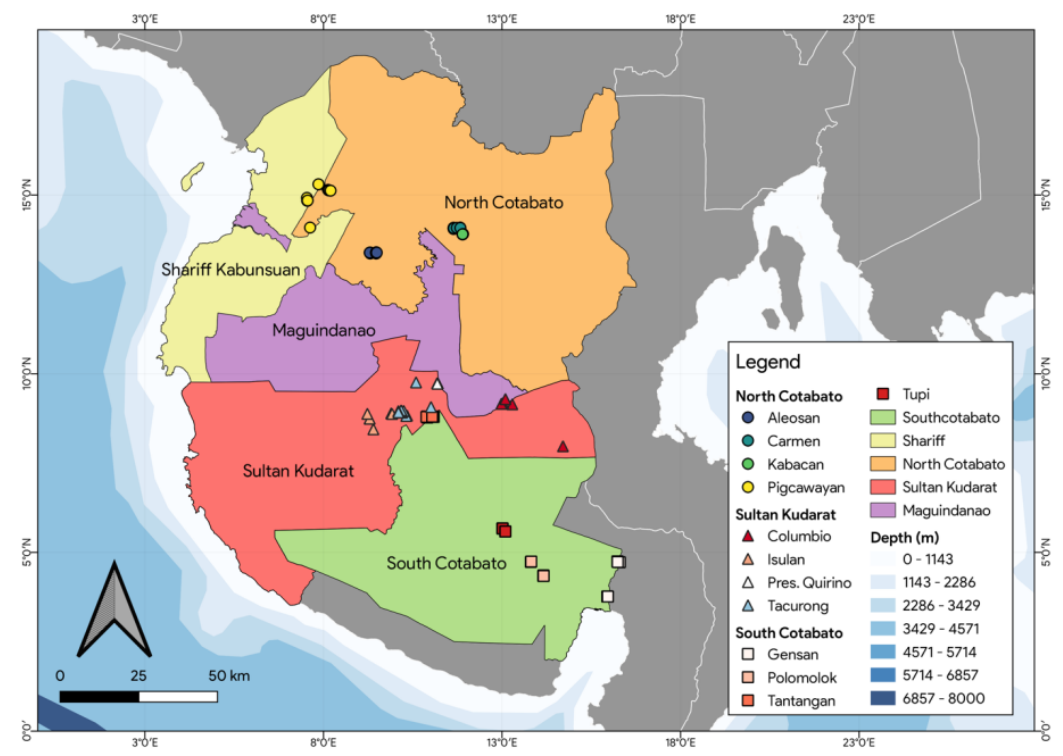

Fig 1. Location of the respondents 


\section{Respondents and sampling procedures}

A total of 131 respondents were interviewed. Prior informed consent was sent to each municipality/city.Meetings with the Provincial Agricultural Officer, Municipal Agricultural Officers, livestock technicians and Barangay Chairpersons of the different barangays with highest concentration of goats were done to discuss the rationale of the study.

Face to face interview was done on selected respondents. A semi-structured questionnaire on cases of toxicosis due to consumption specific forage (e.g., date observed, forage fed, symptoms and other remarks) was used. The amount of forage intake that induce toxicosis was also asked.

Data Analysis

Data analysis and interpretation was done through descriptive statistics including frequency count and percentage.

\section{Results}

Most of the respondents tethered their goats in open vegetated areas with varying species of plants consumed by goats. In this study, a total of 11 plant-related toxicosis were recorded based on the observation and experience of goat raisers (Fig. 2). The most common case is diarrhea due to overconsumption of Gmelinaleaves (29\%). Overconsumption of Gmelinaleaves also caused emaciation (7\%), bloat (5\%) and even led to death (4\%). Moreover, consumption of Chromolaenaodorataleaves caused diarrhea (17\%) and emaciation (4\%). Abortion due to the consumption of Phaseoluslunatusleaves (12\%),Vignaradiatafruit (3\%) and overconsumption of Leucaenaleucocephala(3\%) were also recorded. Diarrhea was also observed by raisers when there is overconsumption of Saccharumspontaneum(3\%) and Manihotesculenta(3\%).

Other plants consumed by goats were also noted to induce toxicity as observed by farmers. These includeCorchorusolitorius and Commelinadiffusa leaves which causes diarrhea, and Gliricidiasepium, which causes bloat, emaciation and increases body temperature.

Irritations caused by plants were also observed by the respondents. Consumption of Mimosa pudicaand Mimosa diplotrichawere noted by respondents to cause wounds near mouth parts.

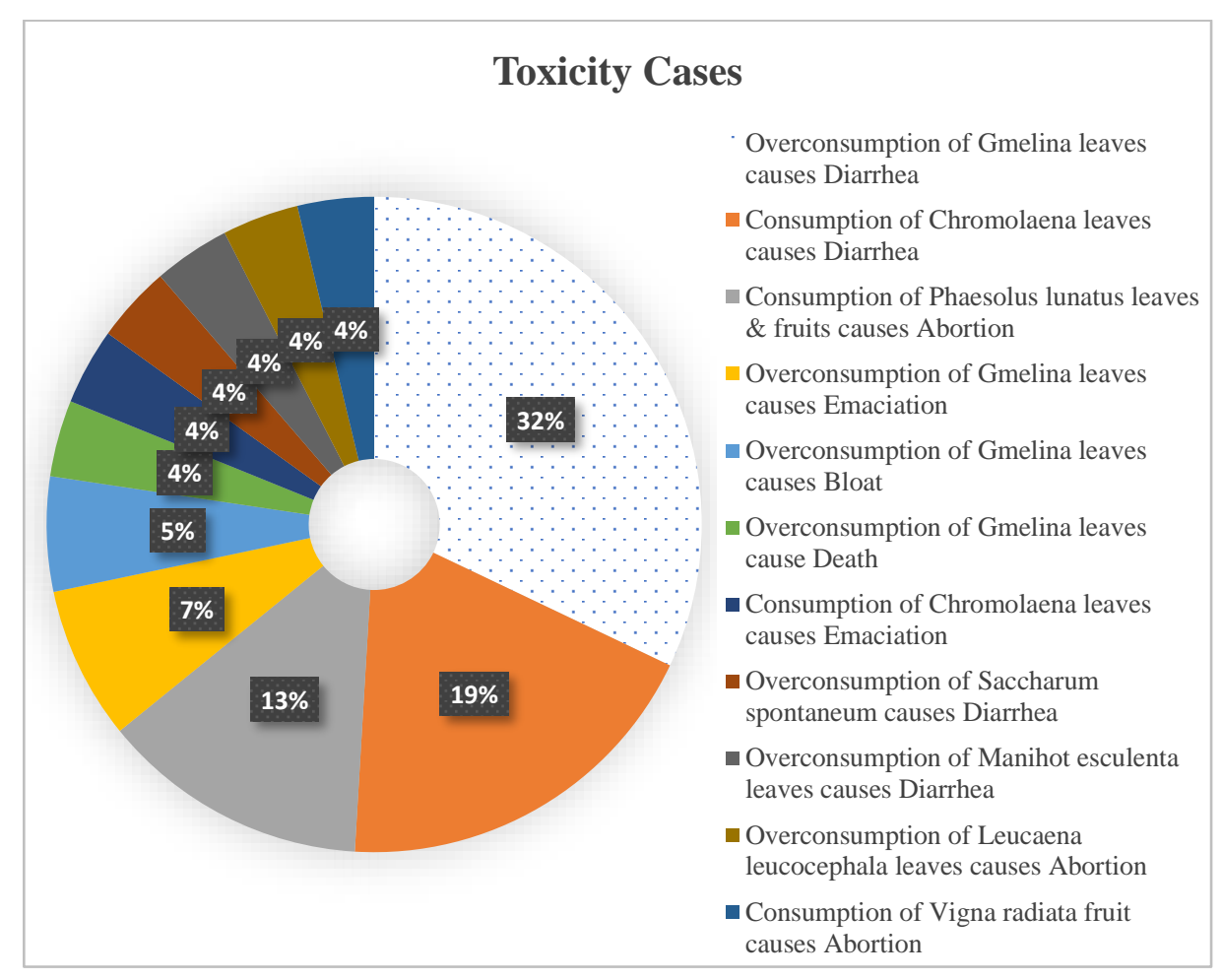

Fig 2.Toxicity cases recorded from goat raisers of Region XII. 


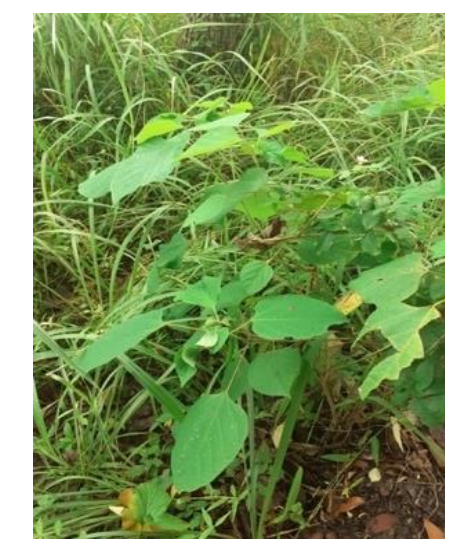

a

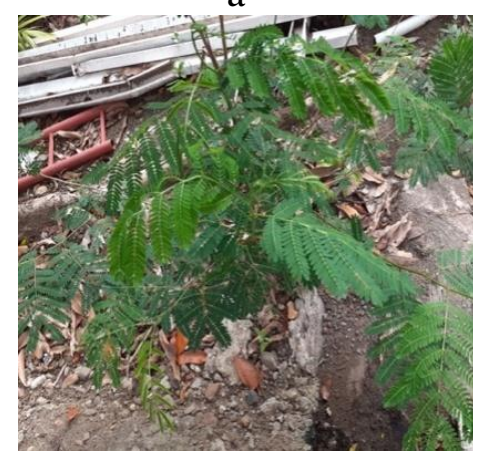

e

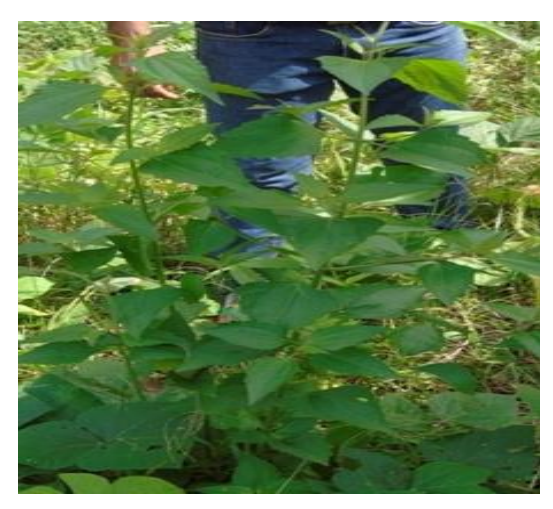

b

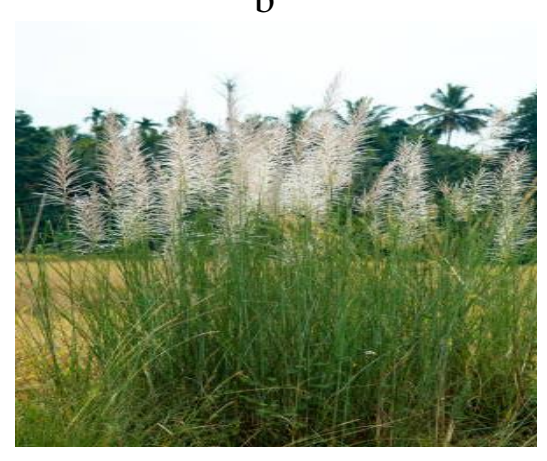

$\mathrm{f}$
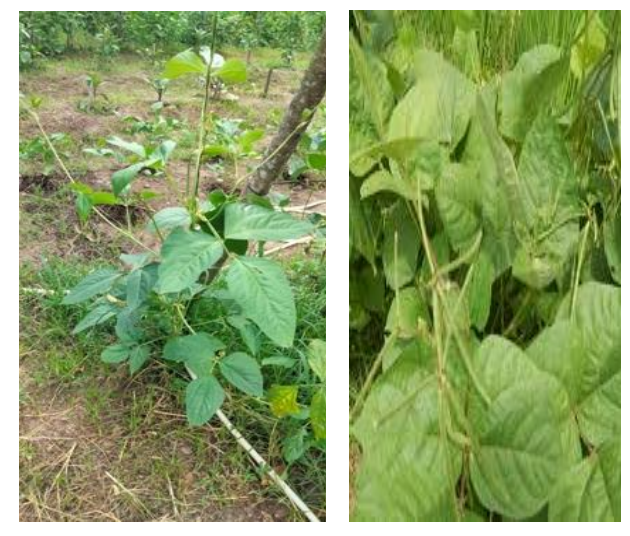

c

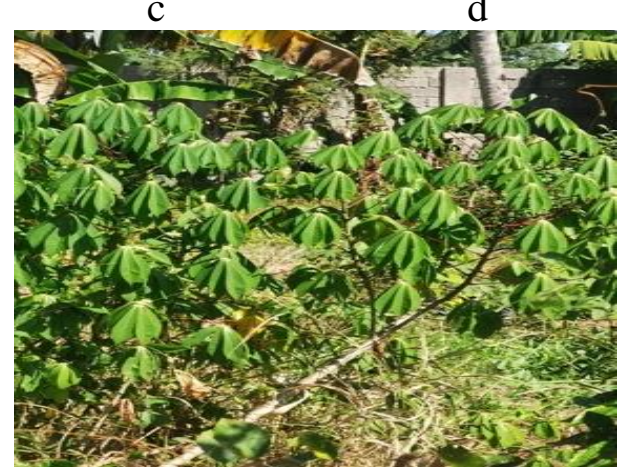

$\mathrm{g}$

Fig 3. Major plant species which induce toxicosis in goats a- Gmelina arborea; b- Chromolaena odorata; c- Phaseo luslunatus; d- Vigna radiata; e- Leucaena leucocephala; f- Saccharum spontaneum; g- Manihote sculenta.

\section{Discussion}

Most cases of toxicosis in this study is commonly attributed to the overconsumption of Gmelina arborealeaves. The leaves of this species are considered as non-conventional feedstuffs which is available all year round. This have been fed to ruminants with appreciable results (Lamidi et al., 2009). As feedstuff, it is rich in protein which ranges from 10.01-38.4\% as reported by Osakwe and Udeogu (2007). Kakengi et al. (2001) have shown that $G$. arborea leaf can be used as cheap protein supplements which can improve voluntary intake, digestibility and the general performance of animals. In addition, the study of Ukanwoko and Okehielem (2016) also elaborated the use of $G$. arboreaas feedstuff and concluded that $20 \%$ inclusion of the leaves in the diet of West African bucks is good for better performance. Despite of these possibilities, laboratory tests conducted by Augustine et al. (2018) revealed that $G$. arborea fruit and leaves contain some toxic components which includes tannins, oxalates, phytates and saponins. Thus, the potentials of $G$. arboreaas livestock feed resources can be maximize when they are properly processed before feeding which requires more studies to determine the best processing methods that will detoxify important parts like fruits and leaves

Chromolaena odorata is an invasive weed in many tropical countries such as India, Australia, Pacific islands, Southern Asia, South Africa, Central and Western Africa (Lina and Ephrime, 2011). The weed is considered unpalatable and is suspected to cause death to domestic animal when ingested especially the leaves (Zachariades et al., 2009). The consumption of $C$. odoratais observed due to limited forage species as this species reduced pasture carrying capacity. High leves of nitrate in young leaves is suspected to be the cause of livestock death and consumption of flowers killed some goats in South Africa (McFadyen, 2004). Another report of Biller et al. 1994 showed that this species contains N-oxides of five pyrrolizidine alkaloids including 7- and 9-angeloyletronecine, intermedine, rinderine and 3-acetylrinderine. According to Gatmaitan (1977), intermedine and rinderine are pyrrolizidine alkaloids that cause liver toxicity.

Legumes like mung bean (Vigna radiata), lima bean (Phaseolus lunatus) and ipil-ipil (Leucaena leucocephala) were noted by the respondents as abortive agents. Phytoestrogens found in legumes, occur as glycosides, can reduce ovulation rates and have been implicated in increased embryonic mortality rates (Mostrom \& 
Evans, 2011). In the study of Sastry \& Singh (2008), large amount of L. leucocephala caused higher percentage of abortion to goats at different stages of gestation. Additionally, Sergio et al. (2019) showed that L. leucocephala extract have similar effects with synthetic xenoestrogen Daidzein. Observed effects include disrupted the estrous cycle and female sexual behavior, decreased the number of follicles and corpora lutea, increased uterine and vaginal epithelium in proestrus and diestrus periods, increased uterine and vaginal relative weights during diestrus, and decreased serum progesterone during proestrus. Mimosine is a pyridine alkaloid known to be toxic found in $L$. leucocephala. One of the observable effect of mimosine in goats is alopecia. However, fetal abortions (Holmes, 1980) and low fertility (Holmes, 1981) are other recognizable symptoms of mimosine toxicity.

Moreover, Saccharums pontaneum is commonly grazed by livestock during forage scarcity, however, it has been reported as good fodder for goats (Thakur, 1984) and suitable for the production of silage (Komarov et al., 1963). In some part of India, poisoning of livestock due to the consumption of this species is attributed to hydrocyanic acid or prussic acid. Poisoning is more likely to occur in ruminants due to the action of rumen microbes (Robson, 2007).

Cassava (Manihote sculenta) is one of the forage species fed to goats. It has a fairly high crude protein content of about $16 \%$. This value is high enough to consider cassava as a good animal feed. However, cassava leaves have not been fully utilized as goat feed due to the fact that it contains anti-nutrition and toxic compounds. It is thought that cyanogenic glycosides (linamarin) could be capable of producing toxic effects (Kamalu, 1995), however Carlsson et al. $(1995,1999)$ observed that linimarin can be absorbed from the gut and excreted intact in the urine. The study of Soto-Blanco and Gorniak (2010) revealed that the toxic effects of the consumption of cassava leaves by goats can be attributed to the action of cyanide released from cyanogenic glycosides.

Some of these recorded plants are utilized as forage by most farmers in the region (Salvaña et al., 2019), however, there are no feeding ratio practiced and observed. The type of forage as well as the level of consumption per forage is not monitored. Toxic effects of compounds in plants are dependent on the level of consumption (Kumar, 1992). Goat farmers in the region are practicing tethering, thus, goats tend to consume plant species within their reach and overconsumption is possible.

Tethering is the most common practice done by goat raisers in the region. In this practice, goats are confined within a restricted location and, more often than not, goats have minimal access to high quality pasture and consumed plants near them (Romney et al., 1996). It is one of the most plausible reasons of consumption and overconsumption of plants identified in this study that induce toxicosis which are abundant in rangeland where goats are tethered.

\section{Conclusion}

In most cases, forage-related toxicosis in livestock are least documented. There are plant species consumed by ruminants, especially goat, which induce toxic effects. Toxicosis can be attributed to the consumption and overconsumption of these plants. Some of these plants, like Leucaena leucocephala and Gmelina arborea, are utilized as forage. Proper feeding management and processing can be done to lessen or eliminate toxic effects.

\section{Acknowledgement}

The researcher would like to express their heartfelt gratitude to: municipal agriculturists, livestock inspectors, veterinarians, respondents and the Philippine Council for Agriculture, Aquatics and Natural Resources Research and Development (DOST-PCAARRD).

\section{References}

1) Augustine C, Khobe D, Madugu AJ, Obidah LU, Solomsi A.A., Tarimbuka LIEdward A. 2018. Chemical Composition of Gmelina (Gmelinaarborea) Fruits and Leaves and Their Adoption as Livestock Feed Resources in Mubi Area. International Journal of Current Innovations in Advanced Research 1(2): 5-11.

2) Biller A, Boppre M, Witte L, Hartman, T. 1994.Pyrrolizidine alkaloids in Chromolaenaodorata. chemical and chemoecological aspects. Phytochemistry 35: 615-619.

3) Carlsson L, Mlingf N, Juma A, RonquistG, Rosling HA. 1995. Specific and sensitive method for the determination of linamarin in urine. Natural Toxins3: 378-82.

4) Carlsson L, MlingfN, Juma A, Ronquist G, Rosling H. 1999. Metabolic fates in humans of linamarin in cassava flour ingested as stiff porridge. Food and Chemical Toxicology 37: 307-12.

5) Damiran D, Darambazar E. 2003. Toxic Plants of Mongolian Rangelands. Union, Oregon, U.S.A.: Oregon State University, Eastern Oregon Agricultural Research Station. 
6) Fagbohun ED, Asare RR, Egbebi AO. 2012. Chemical composition and antimicrobial activities of UrenalobataL. (Malvaceae). Journal of Medicinal Plant Research 6(12): 2256-2260.

7) Gatmaitan OM. 1977. Consumption of Agonoy causes poisoning in rabbits and goats. NSBD Technology Journal, pp.11-19.

8) Holmes JHG. 1980. Toxicity of Leucaena leucocephala. II. Reduced fertility of heifers grazing Leucaenaleucocephala. Papua New Guinea Agricultural Journal 31: 47-50.

9) Holmes JHG. 1981. Toxicity of Leucaena leucocephala for steers in the wet tropics. Tropical Animal Health and Production: 13: 94-100.

10) KamaluBP. 1995. The adverse effects of long-term cassava (Manihote sculenta Crantz) consumption. International Journal of Food Science and Nutrition 46: 65-93.

11) Kakengi AMV, Shem MN, Otsyina R, Mtengeti E. 2001. Performance of grazing cattle in semi+ arid areas of Western Tanzania and the marginal productivity of Leucaena leucocephala leaf meal supplement. Agroforestry System 52: 73-82.

12) Komarov VL,Rozhevits R, Shishkin BK. 1963. Flora of the USSR. Leningrad, USSR: The Botanical Institute of the Academy of Sciences of the USSR.

13) Kumar, R. 1992. Anti-nutritional factors, the potential risks of toxicity and methods to alleviate them. Legume trees and other fodder trees as protein source for livestock. FAO Animal Production and Health Paper 102: 145-160.

14) Lamidi AA, Aina ABJ, Sowande SO, Johosho AO. 2009. Assessment of Panicum (Jacq) Gliricidia sepium and Gmelinaarborea (Roxb) based diets as all year round for West African Dwarf goats. Proceedings of the 14th Annual Conference of Animal Science Association of Nigeria (ASAN) September 14-17th, 2009 Ogbomoso, Nigeria.

15) Lina T, Ephrime B. 2011. Distribution of the invasive plant species Chromolaena odorata L. in the Zamboanga Peninsula, Philippines. International Journal of Environmental Science and Development 2(5): $405-410$.

16) Luginbuhl JM. 2006. Pasture for meat goats. In: Goat Production Handbook, ed. TA Gipson, RC Merkel; K. Williams and T. Sahlur, Langston University.

17) McFdyen REC.2004. Chromolaena in East Timor: history, extent and control. In: Day, MD and McFadyen RE (eds). Proceedings of the Sixth International Workshop on Biological Control and Management of Chromolaena odorata, pp. 8-10. ACIAR Technical Reports 55. Canbera, Australia.

18) Mostrom M, Evans T. 2011. Phytoestrogens. Reproductive and Development. Toxicology: 707-722. Academic Press.

19) Mugera GM. 1970. Phytolacca dodecandra L'Herit toxicity in livestock in Kenya. Bulletin of Epizootic Diseases Africa 18: 41-43.

20) Olafadehan OA. 2011. Changes in haematological and biochemical diagnostic parameters of Red Sokoto goats fed tannin-rich Pteroca rpuserinaceus forage diets. Veterinary Archives 81: 471-483.

21) Osakwe II, Udeogu RN. 2007. Feed intake and nutrient digestibility of West African Dwarf (WAD) goats fed Panicum maximum supplemented with Gmelina arborea. Animal Research International 4: 724-727.

22) Philippine Statistics Authority (PSA). 2018.Selected statistics on agriculture. https://psa.gov.ph/content/selectedstatistics-agriculture

23) Ralphs MH,Provenza FD. 1990. Minimizing toxic plant losses through behavior modification. In: Proceedings West Texas Toxic Plant Symposium. Ft. Stockhon, Texas. pp. 47-54.

24) Robson S. 2007. Prussic acid poisoning in livestock. NSW Department of Primary Industries. State of New South Wales.

25) Romney DL, Sendalo DSC, Owen E, Mtenga LA, Penning PD, Mayes RW, Hendy CRC. 1996. Effects of tethering management on feed intake and behavior of Tanzanian goats. Small Ruminant Research 19: 13-120.

26) Salvaña FRP, Sepelagio EG, Sanchez CB, Besana CM, Kamamang JS, Cardenas LB. 2019. Inventory and diversity of forages utilized by farmers raising goats in Halal way: The case of Region XII, Philippines. Journal of Livestock Science 10: 118-125.

27) Sastry MS, Singh R. 2008. Toxic effect of subabul (Leucaena leucocephala) on the thyroid and reproduction of female goats. The Indian Journal of Animal Sciences 78(3): 251-253.

28) Sergio RP, Susana RM, Alberto DJ, Socorro RM. 2019. Leucaena leucocephala extract has estrogenic and antiestrogenic actions on female rat reproduction. Physiology \& Behavior211: 112683.

29) Soto-Blanco B, Gorniak SL. 2010. Toxic effects of prolonged administration of leaves of cassava (Manihote sculenta Crantz) to goats. Experimental and Toxicology Pathology 62: 361-366

30) Thakur C. 1984. Weed Science. New Delhi, India: Metropolitan Book Co.(P) Ltd.

31) Ukanwoko AI,Okehielem OV. 2016. Effect of gmelina (Gmelina arborea) leaf meal-based diets on goat performance West African dwarf bucks. Asian Journal of Animal Sciences10: 154-158.

32) Zachariades C, Day M, Muniappan R, Reddy GVP. 2009. Chromolaena odorata (L) King \& Rob. (Asteraceae). Cambridge University press, UK. 33pp. 